\title{
Current concepts in hand infections
}

\author{
Tolga Turker \\ From 10th Congress of the Asia-Pacific Federation of Societies of Surgery fo the Hand and the 6th Congress \\ of Asia-Pacific Federation of Societies of Hand Therapists \\ Kuala Lumpur, Malaysia. 2-4 October 2014
}

Hand infections are common occurrences, usually resulting from an injury, that when left untreated can quickly lead to tissue destruction and loss of function or permanent disability. Infections may be categorized anatomically: superficial, involving the tendon and tendon sheath, involving joint or bone, or affecting the deep spaces of the hand. Infections may be caused by different microorganisms, and, increasingly, by communityacquired methicillin-resistant Staphylococcus aureus (MRSA). Currently MRSA accounts for as much as $65 \%$ of Staphylococcus aureus isolates, complicating the course of medical treatment. Brown and Young state that major metropolitan hospitals should expect 25-50 admissions annually for serious hand infection. Hand infections primarily occur after delayed treatment after minor trauma. Laceration, unknown causation, thorn, human bite (e.g., often "fight-bite" injuries), IV injection injury, dog bite, insect bite, blunt trauma, cat bite, snake bite, and pressure injections. The palm or dorsum of the hand, the middle finger and the index finger are most frequent locations of infection. It is reported that the most common hand infections are cellulitis and paronychia/eponychia (70\%) and more severe infections such as septic arthritis and osteomyelitis occur less often (3\%).

A wide variety of approaches to antibiotic treatment have been used and evolved over the years as antibiotic resistance and occurrence of community-acquired antibiotic-resistant infections have increased. Even though the choice of antibiotics is evolving from those used in the past due to changes in microorganisms and developing antibiotic resistance, the treatment principles set forth by Brown and Young of 3-5 days of IV antibiotic treatment followed by 7-10 days of oral antibiotic treatment remains a valid treatment plan for hand infection patients.

Another important issue in hand infections is delay in seeking treatment and/or delayed surgical drainage.
Glass reported that delay in treatment causes slower resolution; for example, if the delay is more than 2.5 days, about $70 \%$ of those patients showed delayed recovery.

Surgical treatment is an important component of clinical management. A detailed, comprehensive initial surgical approach may minimize the need for multiple surgeries. Intraoperative care should be comprehensive, using copious Dakin's solution, hydrogen peroxide, sterile water, and bacitracin in normal saline to irrigate the infected area. Postoperatively, usage of Dakin's solution for immediate soaking of the open wound 1-2 times per day for 10 minutes for 3 days may help to decrease the load of bacteria. Although traditionally, post-operative splinting may be suggested for hand infection treatment, we recommend application of a soft dressing and starting early range of motion exercises in order to decrease stiffness.

In conclusion, with prompt and appropriate care, most soft tissue hand infection patients can achieve full resolution of their infections. Treating infections promptly with surgical incision and drainage using a large incision with copious irrigation and then using a regimen of soaking and use of soft dressing with early range of motion exercises are key to achieving good outcomes and avoiding multiple surgical procedures. In conjunction with surgical treatment, judicious antibiotic treatment is also important. After cultures are obtained, antibiotic treatment should be tailored more specifically to the organisms. Consultation with an infectious diseases specialist can sometimes be helpful in choosing the most appropriate regimen.

Published: 19 May 2015

\section{References}

1. Akdemir O, Lineaweaver W: Methicillin-resistant Staphylococcus aureus hand infections in a suburban community hospital. Annals of plastic surgery 2011, 66:486-7. 
2. Anwar MU, Tzafetta K, Southern SJ: Review of community-referred hand infections. Surg Infect (Larchmt) 2008, 9:357-66.

3. Brown DM, Young VL: Hand infections. South Med J 1993, 86:56-66.

4. Brown H: Hand infections. American family physician 1978, 18:79-85.

5. Carter SJ, Mersheimer WL: Infections of the hand. The Orthopedic clinics of North America 1970, 1:455-66.

6. Eaton RG, Butsch DP: Antibiotic guidelines for hand infections. Surgery, gynecology \& obstetrics 1970, 130:119-22.

7. Fowler JR, Ilyas AM: Epidemiology of Adult Acute Hand Infections at an Urban Medical Center. The Journal of hand surgery 2013, 38:1189-93.

8. Glass KD: Factors related to the resolution of treated hand infections. The Journal of hand surgery 1982, 7:388-94.

9. Houshian S, Seyedipour S, Wedderkopp N: Epidemiology of bacterial hand infections. Int J Infect Dis 2006, 10:315-9.

10. Imahara SD, Friedrich JB: Community-acquired methicillin-resistant Staphylococcus aureus in surgically treated hand infections. The Journal of hand surgery 2010, 35:97-103.

11. Kiran RV, McCampbell B, Angeles AP, et al: Increased prevalence of community-acquired methicillin-resistant Staphylococcus aureus in hand infections at an urban medical center. Plastic and reconstructive surgery 2006, 118:161-6, discussion 7-9.

12. LeBlanc DM, Reece EM, Horton JB, Janis JE: Increasing incidence of methicillin-resistant Staphylococcus aureus in hand infections: a 3-year county hospital experience. Plastic and reconstructive surgery 2007, 119:935-40.

13. McDonald LS, Bavaro MF, Hofmeister EP, Kroonen LT: Hand Infections. The Journal of hand surgery 2011, 36:1403-12.

14. Nicholls RJ: Initial choice of antibiotic treatment for pyogenic hand infections. Lancet 1973, 1:225-6.

15. Nourbakhsh A, Papafragkou S, Dever LL, Capo J, Tan V: Stratification of the Risk Factors of Community-Acquired Methicillin-Resistant Staphylococcus Aureus Hand Infection. The Journal of hand surgery 2010, 35:1135-41.

16. Nunley DL, Sasaki T, Atkins A, Vetto RM: Hand infections in hospitalized patients. American journal of surgery 1980, 140:374-6.

17. Phipps AR, Blanshard J: A review of in-patient hand infections. Arch Emerg Med 1992, 9:299-305

18. Weinzweig N, Gonzalez M: Surgical infections of the hand and upper extremity: a county hospital experience. Annals of plastic surgery 2002, 49:621-7.

doi:10.1186/1753-6561-9-S3-A102

Cite this article as: Turker: Current concepts in hand infections. BMC

Proceedings 2015 9(Suppl 3):A102

\section{Submit your next manuscript to BioMed Central and take full advantage of:}

- Convenient online submission

- Thorough peer review

- No space constraints or color figure charges

- Immediate publication on acceptance

- Inclusion in PubMed, CAS, Scopus and Google Scholar

- Research which is freely available for redistribution 